\title{
Neuromuscular contributions in eight anaesthesia journals
}

Colin A. Shanks MD ChB

Entries in the index issues of eight English-language anaesthesia journals were examined for the years 1950-1990, noting the number of original articles, reviews and editorials. Those which included topics involving neuromuscular blockade were examined in greater detail; these averaged almost one-tenth of the annual totals, despite its eightfold increase over the four decades. During the eighties the strongest research interest involved atracurium, pancuronium, succinylcholine, tubocurarine, and vecuronium, but the share for the long-acting agents was waning by 1990.

On a colligé les sujets des articles, revues et éditoriaux publiés dans huit journaux anesthésiques de langue anglaise au cours de la période allant de 1950 à 1990. Nous avons porté une attention particulière à ceux traitant de curarisation et avons réalisé qu'ils représentaient près d'un dixième du total annuel et ce, malgré son augmentation de $800 \%$ au cours des 40 dernières années. Pendant les années 80, on s'est surtout intéressé à l'atracurium, au pancuronium, à la succinylcholine, à la d-tubocurarine et au vécuronium toutefois, à l'aube des années 90 , l'intérêt pour les curares à longue action allait décroissant.

In 1940 there were three English-language journals devoted to publishing reports of original work in anaesthesia; by 1990 the number had more than doubled. Several new journals have concentrated on more specialized topics, such as regional anaesthesia; others maintain a broad interest in anaesthetic subjects. Despite this enlarged forum for subjects related to anaesthesia, the pressure to increase the number and size of issues appears to be continuing.

\section{Key words}

ANAESTHESIOLOGY: journals;

NEUROMUSCULAR RELAXANTS: atracurium, pancuronium, succinylcholine, tubocurarine, vecuronium.

From the Department of Anesthesia, Northwestem University, 303 East Chicago Avenue, Chicago, Illinois, 60611.

Accepted for publication 3rd May, 1991.
The introduction of d-tubocurarine into clinical practice was one of the factors which contributed to the expansion of academic interest in our specialty. The quest for improved agents and techniques is reflected in developments associated with drug-induced surgical relaxation. This paper examines the numbers of original contributions published in eight anaesthesia journals, and the incidence of studies involving neuromuscular blockade.

\section{Methods}

A database was developed for the material published in eight anaesthesia journals: Acta Anaesthesiologica Scandinavica, ${ }^{2}$ Anaesthesia, ${ }^{3}$ Anaesthesia and Intensive Care, ${ }^{4}$ Anesthesia and Analgesia, ${ }^{5}$ Anesthesiology, ${ }^{6}$ British Journal of Anaesthesia, ${ }^{7}$ the renamed Canadian Journal of Anaesthesia, ${ }^{8}$ and Journal of Clinical Anesthesia. ${ }^{9}$ To highlight the overall expansion of the journals' contents in the years from 1942, material in the index of the year at

TABLE I Original articles in the selected anaesthesia journals, in the year commencing the decade. The annual numbers of anaesthesia articles in the eight Joumals are shown during the 1980's.

\begin{tabular}{llcc}
\hline & & \multicolumn{2}{l}{ Neuromuscular articles } \\
\cline { 4 - 4 } Year & $\begin{array}{l}\text { Total } \\
\text { articles }\end{array}$ & Total & Percent \\
\hline 1950 & 197 & 16 & 8 \\
$(3$ joumals) & & & \\
1960 & 295 & 25 & 8 \\
$(6$ joumals $)$ & & & \\
1970 & 446 & 46 & 10 \\
$(6$ joumals) & & & \\
1980 & 1030 & 98 & 10 \\
$(7$ joumals $)$ & & & \\
1981 & 1023 & 74 & 7 \\
1982 & 1035 & 84 & 8 \\
1983 & 1124 & 124 & 11 \\
1984 & 1176 & 90 & 8 \\
1985 & 1186 & 116 & 10 \\
1986 & 1300 & 151 & 12 \\
1987 & 1443 & 137 & 10 \\
1988 & 1446 & 134 & 9 \\
1989 & 1465 & 142 & 10 \\
1990 & 1580 & 125 & 8 \\
$(8$ joumals $)$ & & & \\
\hline & & &
\end{tabular}


TABLE II The incidence of individual neuromuscular blocking agents named in the titles, 1980 to 1990

\begin{tabular}{|c|c|c|c|c|c|c|c|c|c|c|c|}
\hline \multirow[b]{2}{*}{ Drugs } & \multicolumn{11}{|c|}{ Year } \\
\hline & 80 & 81 & 82 & 83 & 84 & 85 & 86 & 87 & 88 & 89 & 90 \\
\hline Alcuronium & 1 & 3 & 1 & 4 & 5 & 3 & 4 & 8 & 5 & 2 & 6 \\
\hline Atracurium & 0 & 3 & 9 & 45 & 23 & 40 & 66 & 39 & 44 & 38 & 26 \\
\hline Doxacurium & & & & & & & & & 5 & 6 & 4 \\
\hline Gallamine & 4 & 3 & 1 & 0 & 1 & 0 & 2 & 0 & 1 & 1 & 0 \\
\hline Metocurine & 4 & 2 & 4 & 2 & 2 & 5 & 3 & 1 & 2 & 2 & 0 \\
\hline Mivacurium & & & & & & & & & 3 & 11 & 3 \\
\hline Pancuronium & 23 & 13 & 21 & 26 & 17 & 18 & 19 & 20 & 24 & 14 & 6 \\
\hline Pipecuronium & & & & & & & & & 3 & 6 & 5 \\
\hline Succinylcholine & 24 & 21 & 21 & 35 & 22 & 17 & 28 & 39 & 33 & 30 & 30 \\
\hline d-Tubocurarine & 16 & 6 & 14 & 11 & 12 & 9 & 8 & 14 & 4 & 4 & 7 \\
\hline Vecuronium & 23 & 8 & 15 & 26 & 13 & 29 & 40 & 42 & 49 & 40 & 26 \\
\hline
\end{tabular}

the commencement of each decade was examined. Entries related to neuromuscular blockade were extracted, enabling identification of their proportionality during 50 years of anaesthesia literature.

From 1980 onward, the indexes were examined annually. Files were constructed which included only original articles, editorials and reviews in these journals, but omitted the correspondence. Individual mention of the neuromuscular blocking agents studied in the period from 1980 to 1990 was recorded, to detect recent changes in emphasis of research interest. This differs from the annual rating in that a single title can contain the names of several drugs.

\section{Results}

The total numbers of original articles for the decade years of 1950 to 1990 are shown in Table I. Despite a considerable increase in absolute numbers, the incidence of titles related to neuromuscular blockade remained remarkably constant at 8 to $10 \%$. The years intervening between 1980 to 1990 are also included in Table I. The decade showed an increase in the total number of original articles by approximately $50 \%$, yet the proportion of neuromuscular articles continued to be between 7 and $12 \%$ of these totals (Table I).

In 1970 the most commonly reported muscle relaxants were succinylcholine and tubocurarine; pancuronium had not long been introduced. By 1980 pancuronium had begun to displace tubocurarine, but succinylcholine had held its own. In 1980 and 1981 the new entrants were vecuronium and atracurium, respectively, followed in the late eighties by studies involving doxacurium, mivacurium and pipecuronium (Table II).

\section{Discussion}

Neuromuscular research thrives, providing almost onetenth of the articles found in journals broadly devoted to anaesthesia research, and that despite the rapid increase in the number and content of such journals (Table I). Limitation in scope to eight journals allowed development of a denominator, to quantify the relative interest in neuromuscular studies within the specialty. As the study excludes journals devoted to the superspecialties and to related basic sciences, such as cardiovascular anaesthesia and pharmacology, and those in foreign languages, this restriction precludes derivation of the grand total of all such studies available in the world literature. For example, Table II does not list entries for pipecuronium before 1988, missing the early European studies. Neither does Table II reflect the incidence of reviews or other neuromuscular literature contained in journals and textbooks.

Table II gives details of agents studied in the period 1980 to 1990 , and attempts to identify changing emphasis in research. At the time of writing, 1990 was the last full year in which a complete index was available. While Table II excludes mention of agents in which interest has waned, such as decamethonium and fazadinium, it does retain listings of the fast-fading paleorelaxants: alcuronium, gallamine and metocurine. It seems unlikely that the prototype, d-tubocurarine, can provide enduring research appeal for its next half-century.

Almost as old clinically, succinylcholine reigns supreme as the ultrashort neuromuscular blocking agent. Its clinical success is not promoted in most of the entries in Table II: the majority of the research topics relate to some undesirable feature of its pharmacology. Atracurium and vecuronium are rivals in the intermediate-duration group, in research papers as in clinical practice. Mivacurium is unopposed as the only short-acting agent, but awaits wide public exposure. Doxacurium and pipecuronium have now been launched into the clinical arena.

The contribution of studies involving neuromuscular blockade has remained at approximately ten percent of the total articles in eight anaesthesia journals, despite an 
increase in total published output. This suggests that the field has maintained its support not only in academic departments, but also within the pharmaceutical industry and the funding agencies.

\section{References}

1 Griffith HR, Johnson GE. The use of curare in general anesthesia. Anesthesiology 1942; 3: 418-20.

Index issues of:

2 Acta Anaesthesiol Scand 1960-1990; 4-34.

3 Anaesthesia 1960-1990; 5-45.

4 Anaesth Intensive Carc 1980-1990; 8-18.

5 Anesth Analg 1950-1990; 29-71.

6 Anesthesiology 1950-1990; 1-73.

7 Br J Anaesth 1950-1990; 22-65.

8 Can Anaesth Soc J and Can J Anaesth 1960-1990; 7-37.

9 J Clin Anesth 1987-1990; 1-4. 